\title{
IMPACT OF PILGRIMAGE TOURISM TO THE SHEIKH QURO'S TOMB KARAWANG ON THE LOCAL COMMUNITY QUALITY OF LIFE
}

\author{
Nungky Puspita, I Made Adhi Gunadi, Lita Nuradawiah. \\ Faculty of Tourism Universitas Pancasila. Indonesia. \\ nungkypuspita@univpancasila.ac.id
}

\begin{abstract}
The pilgrimage tour of Syekh Quro is the religious tour in Karawang located in Pulobata, Pulokalapa village, Lemahabang Wadas district, Karawang regency, West Java Province. This research is aimed to identify the impact of the religious tour activity of Syekh Quro's Tomb toward local society quality of life. The research method used in this research is descriptive qualitative. The finding showed that the tourism impact toward local society quality of life clarifies that pilgrimage tourism gives a positive impact on Pulobata communities. These positive impacts are seen in the aspects of material wellbeing, community wellbeing, emotional wellbeing, and health and safety wellbeing.
\end{abstract}

Keywords: pilgrimage tour, tourism impact, quality of life, local community

\section{INTRODUCTION}

Pilgrimage tourism potential in Indonesia is enormous since Indonesia has been known as a religious country. Many of the buildings or historic sites have special meaning for people of faith. Besides a large number of residents of Indonesia, where nearly all of them are religious people, its a potential for the development of religious and pilgrimage tourism (Gagas Ulung, 2013). One of pilgrimage tourism in this country is located in West Java province ie. Karawang.

Pilgrimage tourism is a kind of travel associated with religion, beliefs or customs in society. Pilgrimage performed either by an individual or group visiting the holy places, tombs of saints or famous people and honoured leaders. The aim of this tourism is to get a blessing, happiness and tranquillity. The attraction type is widely associated with religion, history, customs and beliefs of a group of people to a sacred place, to the tombs of the great, to sacred and historic hill or mountain (Purwadadi, et al., 2006). Thus the pilgrimage tourism can be considered as special interest tourism.

Karawang Regency has seven priorities of the development and structuring of tourism destinations including Tanjung Pakis Beach, Batu Jaya Site, Sheikh Quro's Tomb, Proclamation Monument, Green Canyon, Tanjung Baru and Kampung 
Budaya. One of the seven priorities of the development and structuring of tourism destinations which are visited by tourism from local and outside Karawang is pilgrimage tour to the Sheikh Quro's Tomb located in Pulobata, Pulokalapa Village, Lemahabang Wadang District, Karawang Regency of West Java Province. Karawang is an industrial area which still keeps the local traditions; one of the tradition is a pilgrimage to the tomb of Islamic broadcaster Qurotul'ain Shaykh or Sheikh Hasanuddin or Sheikh Mursahadatillah. According to the script of Purwaka Caruban Nagari, Sheikh Quro is a scholar who was wise and prudent. He was also a hafidz Qur'an as well as Qiro'at experts with a very melodious voice. He is the son of a great scholar of Islamic schools of the Campa State named Sheikh Yusuf Siddik who has a lineage with Sheikh Jamaluddin Akbar Al-Husaini and Sheikh Jalaluddin; both were great scholars of Mecca (Disbudpar, 2015).

Based on the number of tourists who visited the Sheikh Quro's Tomb, it showed the impact on the quality of local community' life. Every individual has a different quality of life depends on the way how each person is addressing the problems that occur in him. If they face the problem with positive attitudes they will need better quality of life, but when faced with negative then the quality of life will be bad (Kreitler \& Ben 2004 in Nofitri 2009). Pulobata community mostly spends their time to work in the area of the Sheikh Quro's Tomb, so the impact of pilgrimage tourism activities can affect the quality of life of local community.

To create a leading tourism destination (Cooper 1993) four major aspects (4A) should be studied, namely attraction, accessibility, amenity and ancillary.

1. Attraction

Attraction is the main product of a destination. Attraction is very close related to what to see and what to do. What to see and do by travelers in these destinations. Attractions can be the beauty and uniqueness of nature, local culture, heritage of historic buildings, as well as artificial attractions such as means of games and entertainment. Supposedly, an attraction must have high differentiation value, unique and different from any other area or region.

\section{Accessibility}

Accessibility is the facilities and infrastructure to get to the destination. Highway access and also the availability of means of transportation and road signs are important aspects for a destination. There are so many areas in Indonesia with natural beauty and cultural fit for sale to tourists, but do not have good accessibility, so that when it is introduced and sold, not many tourists are attracted to visit. It should also be noted that good road access alone is not enough without being accompanied by the availability of means of transportation. For the individual tourist, public transport is very important because most of them set up their own way without the help of a travel agent, so it relies heavily on infrastructure and public facilities.

\section{Amenity}

Amenity is all the supporting facilities that can meet the needs and desires of tourists during they stay in destinations. Amenity related to the availability of accommodation facilities to stay as well as a restaurant or a shop to eat and drink. Other needs that may also be desired and needed by tourists, such as public toilets, 
rest areas, car parks, health clinics, and places of worship should be available at a destination. Of course, these facilities also need to consider and examine the situation of their own destinations and tourist needs. Not all amenities must be contiguous and located in the main area of destination. Natural destinations and historic heritage should be rather far apart from amenities for commercial purposes, such as hotels, restaurants and rest area.

\section{Ancillary}

Ancillary related to the availability of an organization or people who manage these destinations. This is important because although the destination already has good attraction, accessibility and amenity, if no regulation or manager, the tourism destination will definitely be abandoned in the future. Organization of a destination will perform his duties as a company. They can manage the certain destination until it can provide benefits to interested parties such as governments, local community, tourists, the environment and other stakeholders.

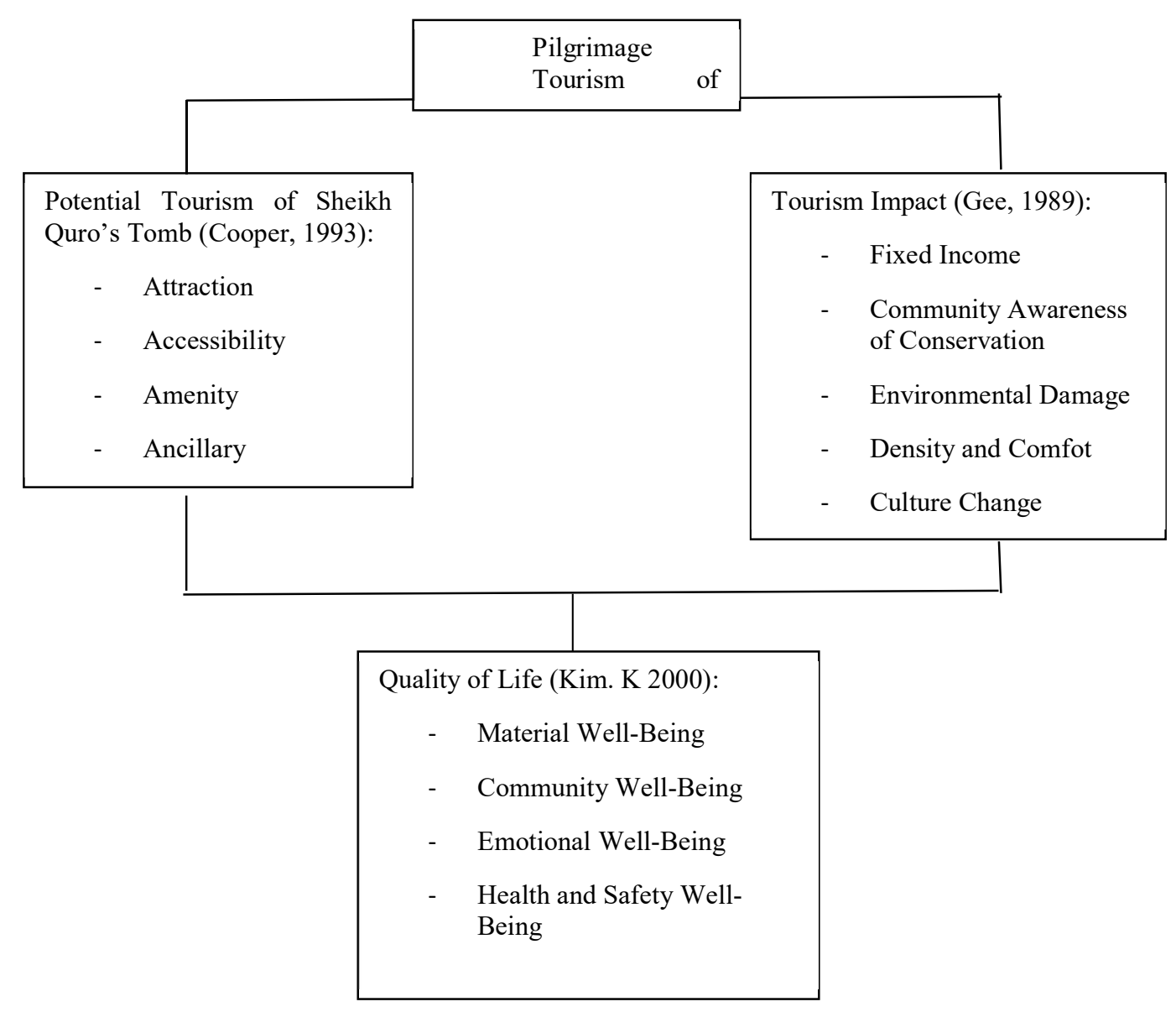

Source: Personal Concept, 2016

Based on the data traffic of tourists visiting the Sheikh Quro's Tomb, it was showed that the visitors had reached 60,000 tourists at the beginning of 2016 until July 2016 
(Disbudpar, 2016). By visiting pilgrimage Sheikh Quro's Tomb, tourists are not only able to travel but they can also increase the value of religion. The pilgrimage tourists not only get pleasure in traveling but get peace of heart, increasing the level of spirituality, for missionaries, or pleasure spiritual. This kind of tourism activities can help improve the quality of life of local people, since Karawang community still have deficiencies, including material well-being, community well-being, emotional well-being, and health and safety well-being.

Kim, K (2000) states that after the people have a goal, the lives of people in community affected by tourism, and the support of the citizens is very important for the planning, development, successful operation and sustainability of tourism.

Hence Kim. K (2002) described the factors influencing the quality of life includes four domains, namely

1. Material Well-Being

Satisfaction of material well-being may be distributed in the form of cost of living and income and employment. Three items for cost of living and four items of income to measure job satisfaction of residents.

2. Community Well-Being

Many aspects of people's lives and regulations shape public appreciation or greater dissatisfaction than in an environment where they stay for life. Four items were used to measure the area of community well-being.

3. Emotional Well-Being

Emotional well-being can be fulfilled in the form of prosperity, leisure and spiritual well-being. Four items for the leisure well-being and five items for the spiritual well-being proposed to measure the satisfaction of the population of emotional well-being.

4. Health and safety Well-Being

Satisfaction of the health and safety well-being consists of health well-being and safety well-being. Two items for the health and three items for the safety were used to measure health and safety well-being.

Based on the background, the research problems to be discussed were:

1. What is the potential of the Sheikh Quro's Tomb as a pilgrimage tour in Karawang?

2. What are the impacts of pilgrimage tourism activities on the Sheikh Quro's Tomb on the quality of life of the local community?

\section{METHODOLOGY}

Sugiyono (2009: 6) said that naturalistic method is used in qualitative research, where this method took place in the natural/origin place and the researchers collected data based on the views of a resource instead of the views of researchers. The study design is used because researchers wanted to know and understand the opinions of the individual (respondents) to a phenomenon and then describe it later. 


\section{Data Validation}

Data validation (validity test of the data) on qualitative research had the same connotations with validation on quantitative research, does not align with reliability (stability and consistency test of respondents) as well as with generabilitas (Creswell, 2012; 284). Sugiyono (2009: 270) reported validation of qualitative is an attempt of examination of the research results accuracy by applying certain procedures, while the reliability of qualitative indicated that approach used by the researchers is consistent to be applied by other researchers and for different projects, data validity test in qualitative research include the credibility test, transferability test, reliability and confirmability test.

\section{Data Analysis}

Data analysis was conducted in this research based on models analysis of Miles Huberman (Sugiyono, 2009; 246-253). Activities conducted were in three stages namely;

\section{Data Reduction/Summarize}

According to Miles and Huberman data reduction means summarizing, selecting subject matter, focusing on the important things and looking for themes and patterns (Sugiyono, 2009; 247). Data reduction function is to organize the data to be easily deduced.

\section{Data Display/Presentation}

Data display or presentation of the data in this study can be done in the form of brief descriptions, charts and so forth. Miles and Huberman found that the form of presentation of data most often is used in qualitative research of narrative texts, (Sugiyono, 2009; 249). The purpose of presenting data is to facilitate researchers and readers in summing up the data obtained in the study.

\section{Conclusion}

At this stage, early tentative conclusion will be found by the evidence in the field. Sugiyono (2009: 252) argued that the conclusions in qualitative research could answer the problem formulation, but it can also possibly not. This is because the formulation of the problem is temporary and may develop after the researchers were in the field.

\section{RESULTS AND DISCUSSION}

1. Tourism potential of Sheikh Quro's Tomb as pilgrimage tourism in Karawang

2. Attraction

3. There are several tourism attractions on the Sheikh Quro's Tomb as follows::

4. Sheikh Quro's Tomb / Sheikh Hasanuddin

5. Tomb of Sheikh Abdillah Dargom or known as Sheikh Bentong, a disciple of Sheikh Quro. 
6. Kolam Pentilasan of Prabu Siliwangi

7. Karawang Grand Mosque in the western part of square of Karawang Kulon Village, West Karawang District, West Karawang Regency

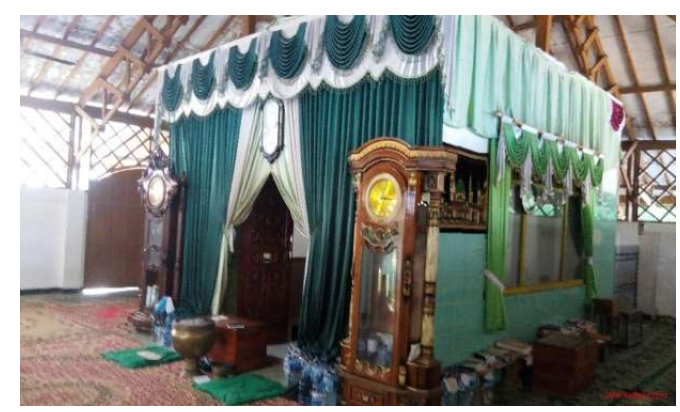

$$
\text { Syekh Quro tomb }
$$

Source: Personal Documentation , 2016

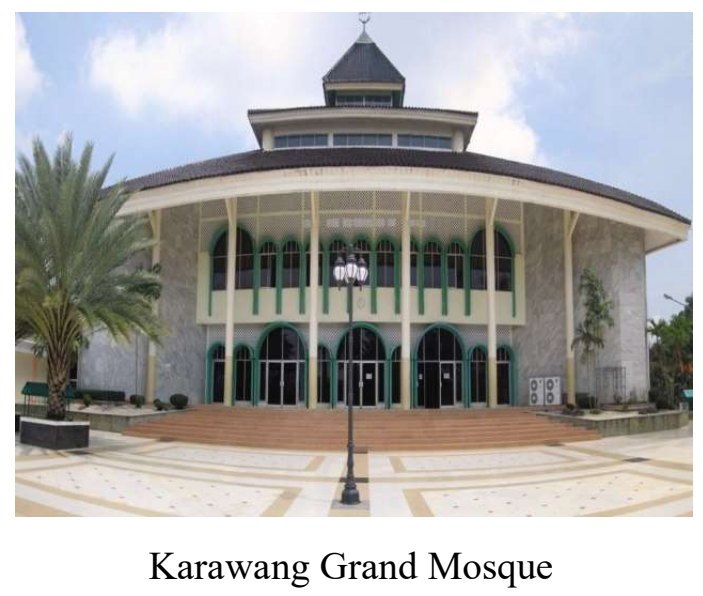

Source: Dinas Kebudayaan dan Pariwisata Karawang, 2015

\section{- $\quad$ Accessibility}

The location of the Sheikh Quro's Tomb is at the Pulobata, Pulokalapa village, Wadas District of Karawang regency. Based on observations and interviews it is required $28 \mathrm{~km}$ from Karawang town center to the Sheikh Quro's Tomb. Travelers who have never visited the Sheikh Quro's Tomb do not have to worry as there will be signs guide every 5 to $10 \mathrm{~km}$ along the way to the Sheikh Quro's Tomb, so it will be easier for tourists to reach the Sheikh Quro's Tomb. 


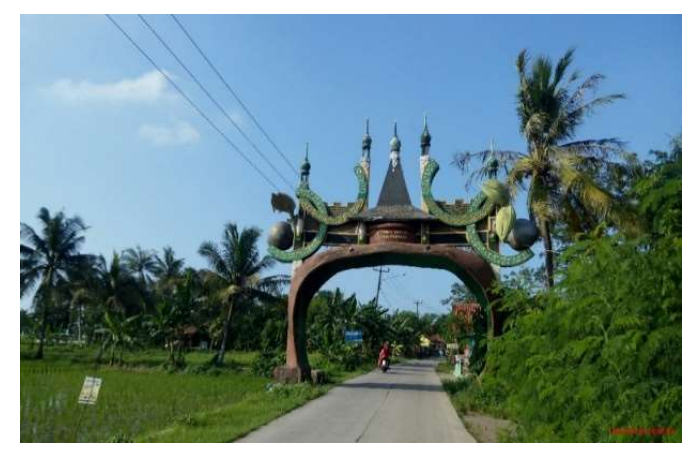

Road to Syekh Quro

Source: Personal Documentation, 2016

\section{- $\quad$ Amenity}

The adequate amenities or facilities for the pilgrims are available among others prayer room, public toilets, parking lot, kiosk for trade. Sheikh Quro's Tomb does not have a mosque, only a mushola/prayer room. When the researchers conducted interviews with the village manager and Disbudpar, they said that they would put more attention to the facilities, especially for the mosque.

- Ancillary/Institutional

Based on the results of interviews with the Pulobata village they said that the management of Sheikh Quro's Tomb is supported by the Karang Taruna of the local community. These activities have been approved by the head manager ie. the head of the Pulobata village.

2. The impact of pilgrimage tourism activities to the Sheikh Quro's Tomb on the quality of life of local community.

Quality of life can be measured on the well-being of the people residing in the environment of tourism. In this case Pulobata quality of life can be measured on four ways:

\section{1) Material Well-Being}

Based on the results of interviews with Pulobata community about the material well-being perspective, it can be said that Pulobata community is prosperous. They raise money by trading and working in the area of the Sheikh Quro's Tomb in order to increase income so that the cost of living will be fulfilled. With the increasing income, the Pulobata community can do the following:

1. Fixing damaged house

2. Education children

3. Getting nutritious food

4. Investment 


\section{2) Community Well-Being}

From observations and interviews with community, they feel comfortable and prosperous in the neighborhood, because they have involved in the tourism management of Sheikh Quro's Tomb for years. And over the years the Pulobata community's quality of life began to increase. The number of tourists who come to the Sheikh Quro's Tomb can create job opportunities for the local community. So they can earn a living and fulfill their needs by involving in these opportunities.

3) Emotional Well-Being

Emotional well-being for the Pulobata community can be seen from their free time during their work on the Sheikh Quro's Tomb. With free time, people can do the job with a sense of fun and unencumbered, as most of them are working in the pilgrimage tourism area of the Sheikh Quro's Tomb.

4) Health and Safety Well-Being

Regarding the health and safety, the pilgrimage tourism activity impacts the Pulobata community. Since the visit of pilgrims can help to improve the economy of the local community, therefore Pulobata community put more attention in terms of health and safety.
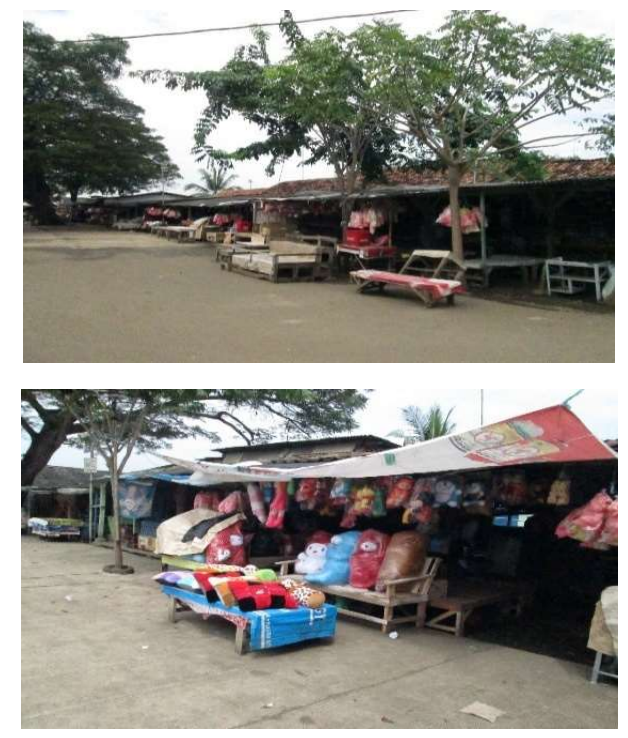

Street Vendor around Syekh Quro

Source: Personal Documentation, 2016

\section{CONCLUSION}

Pilgrimage tourism potential in the Sheikh Quro's Tomb based on 4A aspects, namely attraction, accessibility, amenity, and ancillary is considered good enough. From the attraction aspect, this tourism destination is good to be visited and it also has a variety of other supporting attractions for the tourists. Accessibility is also considered good, seen from the road which is paved and nice with clear 
driving directions and the available public transportation. Regarding the amenity, it is quite adequate since there are the public toilet, mushola, merchandise shop, parking lot. But there still no hotel accommodation, thus the managers provide assemblies for tourists who come from outside the Karawang to stay. Regarding the institutions, Sheikh Quro's Tomb receives support from the organization of Karang Taruna.

Pilgrimage tourism to Sheikh Quro's Tomb showed a positive impact on the quality of life of Pulobata community. From the perspective of the material wellbeing, the community of Pulobata mostly work in the area of the Sheikh Quro's Tomb, so that they can fix the damaged homes, pay for school fees, afford healthier food, and join the investment. Community well-being was seen from how people feel comfortable and prosperous since they earn from working at Sheikh Quro's Tomb and meet the needs of their economy. Emotional well-being can be seen from the free time of the community during working in the area of the Sheikh Quro's Tomb, because with the free time that people can do the job with pleasure. Health and safety well-being showed good effects, indicated that the public could provide good quality food and a healthier community. However, it is still negative trends in terms of environmental damage because there are many tourists who are less protecting the environment when traveling around the Sheikh Quro's Tomb.

\section{REFERENCES}

Abdillah Fitri, dkk: 2014. Perkembangan Destinasi Pariwisata, Benarkah Memang Meningkatkan Kualitas Hidup Masyarakat. SEMNASPAR- CFP: 63-82.

Cooper, C. Fletcher. Jhon, Gilbert, David and Wanhil Stephen. 1993. Tourism: Principles and Practice. London: Pitmen Publishing.

Cummins. R. 1997. The Domain of Life Satisfaction: an attempt to order chaos. Social Indicator Research No. 38. 303-328.

Creswell, Jhon W. 2012. Research Design Pendekatan Kualitatif, Kuantitatif, dan Mixed. Terjemahkan oleh Achmad Fawaid. Yogyakarta: Pustaka Pelajar.

Dewan Keluarga Masjid Agung Karawang. 1993. Sejarah dan Peranan Masjid Agung Karawang dalam Pembinaan Umat yang Beriman dan Bertakwa. Karawang: DKM Agung Karawang.

Dinas Kebudayaan dan Pariwisata Kabupaten Karawang. 2015. Rencana Stratejik Dinas Kebudayaan dan Pariwisata Kabupaten Karawang 2015. Disbudpar Karawang.

Gee. J. P. 1989. "Discourses, Socially-Culturally Situated Educational Theory, and the Failure Problem".

Hancock. T. 2000. Quality of Life Indocator and the DHC. Kleinburg. Ontario: Health Promotion Consultant. 
Kim. K. 2002. The effect of tourism impacts upon Quality of Life of residents in the community. Blacksburg. Journal Vol 8 Issue 2. Virginia: Virginia Polytechnic Institute and State University.

Kusmayadi dan Endar Sugiarto. 2000. Metodologi Penelitian Dalam Bidang Kepariwisataan. Jakarta: Gramedia Pustaka Utama.

Nurrahmah Hana. 2013. Tradisi ziarah kubur studi kasus perilaku masyarakat muslim karawang yang mempertahankan tradisi ziarah pada makam syekh quro di kampong pulobata karawang tahun 1970-2013. Skripsi. Fakultas Adab Dan Humaniora. Universitas Islam Negeri Syarif Hidayatullah: Jakarta.

Nofitri, NFM. 2009. Gambaran Kualitas Hidup Penduduk Dewasa pada Lima Wilayah di Jakarta. Skripsi. Universitas Indonesia Depok.

Sugiyono. 2009. Metode Penelitian Kuantitatif, Kualitatif dan R\&D. Bandung: Alfabeta.

Supardi. 2005. Metodologi Penelitian Ekonomi dan Bisnis.Yogyakarta: UII Press

Thalia, Zajma, dkk. 2011. Pengembangan Wisata Budaya Berbasis Wisata Ziarah Sebagai Wisata Minat Khusus di Kabupaten Karanganyar. Jurnal penelitian Humaniora Vol: 12 91-99

Ulung, Gagas. 2013. Wisata Ziarah, 90 Destinasi wisata ziarah dan sejarah di Jogja, Solo, Magelang, Semarang, Cirebon. Jakarta: PT Gramedia Pustaka Utama.

UNWTO. 2013. Perkembangan pariwisata menjadi industri. https://ardana45.pengaruh-perkembangan-pariwisata-terhadap-strukturperekonomian-dan-kesejahteraan-masyarakatbali.com/2013/05/15/. Diakses 07 April 2016.

Veenhoven. R. 1992. Social equality and state welfare effort: more incomeequality. No more equality in quality of life. Munich: Munich Person RePEc Archive.

Wijayanti Harum Sutaryo, 2014. Pengaruh Tradisi Ziarah terhadap Dinamika Ekonomi Masyarakat Kota Gede (Studi Kasus Dikomplek Pemakaman Raja-Raja Mataram). Skripsi. UIN Sunan Kalijaga Yogyakarta.

Yoeti, Oka A,. 1996. Pengantar Ilmu Pariwisata, Penerbit Angkasa, Bandung: Angkasa. 